\title{
Article \\ Supply Chain Collaboration for Transparency
}

\author{
Alessandro Brun ${ }^{1}$, Hakan Karaosman ${ }^{2, *}$ and Teodosio Barresi ${ }^{1}$ \\ 1 Politecnico di Milano School of Management, 20156 Milano, Italy; alessandro.brun@polimi.it (A.B.); \\ teodosio.barresi@mail.polimi.it (T.B.) \\ 2 UCD College of Business, University College Dublin, Dublin, Ireland \\ * Correspondence: hakan.karaosman@ucd.ie
}

Received: 30 March 2020; Accepted: 23 May 2020; Published: 29 May 2020

\begin{abstract}
From an interdisciplinary theoretical perspective, this study uncovers how and to what extent building supply chain relations impacts supply chain transparency in an industrial context characterized by mistrust, complexity and privacy. By conducting a case study involving a multinational fashion group and an influential NGO, this study investigates how a fashion group forms supply chain relations that eventually influence their transparency performance. The fashion group under investigation initially started disclosing information about their supply chain actions in order to ensure legitimacy and protect the brand image. Nevertheless, the group started sharing more information about their supply chains, changing the perspective from a legitimacy driven reactive approach toward an ethics driven proactive approach. Particularly, supplier engagement, commitment and leadership appear to be antecedents to supply chain transparency. The study also reveals the novel influence of NGOs on supply chain transparency. Fashion Revolution has been substantial to drive fashion companies to obtain and disclose information about their supply chains. Supply chain visibility and stronger partnerships are required to overcome problems relating to supply chain complexity on the way toward transparency. Results suggest that supply chain engagement is fundamental for supply chain transparency, and that NGOs play a pivotal role to enhance transparency through knowledge sharing and awareness increasing. The results provide numerous implications that can help industrial practice and research improve the status quo.
\end{abstract}

Keywords: transparency; fashion industry; case study; sustainable supply chain management; fashion sustainability; supply chain relations; relational theory; collaboration; power

\section{Introduction}

Undoubtedly, the industrial growth witnessed in the last century resulted in significant societal as well as economic benefits, including the increase in wealth, prosperity and living standards. Nevertheless, while all of these positive outcomes being registered, alarming side effects also emerged, which in turn have affected social and environmental equilibria causing inequalities. As these issues were getting pretty evident, public opinion started questioning the impacts of human actions on the finite natural resources. Accordingly, this awareness was transformed into a visionary concept as the sustainable development defined by the World Commission on Environment and Development [1], that is, "the development that meets the needs of the present without compromising the ability of future generations to meet their own needs". Initial concerns predominantly focused on environmental sustainability, leading to a growing interest in green supply chain management (GSCM) [2]. In the 2000s, both research and practice evolved into a larger domain, sustainable supply chain management (SSCM), by including both social and environmental dimensions [3]. SSCM domain and a wide range of theories applied within acknowledge the fact that organizations pursuing the desire of economic growth have also environmental and social responsibilities. 
Globalization and growing dependence on supply networks have resulted in resources exploitation, and, consequently, in a number of critical social and environmental issues [4]. As such, when companies pressure their suppliers to have production done faster and cheaper, the suppliers, particularly those located in low-cost counties, might engage in risky behavior such as child labor or overtime [5]. Nonetheless, such unethical actions taken by the suppliers entail reputational and economical risks for the brands [6]. Frequently recorded scandals, including the manufacturing building collapse [7], child labor [8], toxic chemicals [9], mass worker fainting [10] result in reputational damages [11] while, at the same time, show that the industrial settings we operate in, for example the fashion industry [12], is not sustainable. The current state of natural resource scarcity combined with the populational growth underlines that the change cannot to be postponed any longer.

Among the various industries, fashion emerges as an interesting industry that is dependent upon globally dispersed, complex and fragmented supply networks [13]. The fashion industry is the world's third biggest manufacturing industry behind only automotive and electronics and it is generally defined as the industry that deals with making and selling clothes. Being one of the most polluting industries in the world [14], fashion is characterized by low supply uncertainty ang high demand uncertainty [15], short product life cycles [16] (especially in fast fashion segment), tremendous product variety [12] and complex as well as fragmented supply chains [17]. All these aforementioned aspects make the management of fashion supply chains an extremely complex activity [18]. The main actors involved in fashion supply chains are raw material producers, manufacturers, contractors and retailers with the majority of the environmental as well as the social impact being generated at raw material production and processing stages [19].

Apparel manufacturing starts with the product design, usually some weeks before the production. The design stage is essential in this industry, and is almost never outsourced by the brand company, unlike production. In fact, since the 1960s the majority of the fashion industry has been relying on sub-contractors to produce garments. Despite the growth of technological innovations, the fundamental process of sewing remains labor-intensive [20] with capital and knowledge requirements not significant. This puts pressure on manufacturers to search for low-income environments to locate factories, often leading to issues in terms of industrial safety and workers exploitation. The majority of labor is therefore located in low-income countries and composed of young people, mostly female, e.g., $80 \%$ of 75 millions working in fashion supply networks are female between the ages of 18-24 [21].

Despite its direct impact on sustainability in terms of natural resources [22] and social sustainability [23], this industry is not widely investigated by the academic community [3] even though there exist a number of curious research avenues. Sustainability encourages the responsible use of scarce natural resources while sustainability and fashion, particularly luxury, is often considered an oxymoron due to certain material choices and social segmentation. It is considered difficult to ensure sustainability when there are a number of factors that are critical for the market success [24] that might become questionable to ensure responsibility.

Environmental concerns are pretty well-known in the fashion industry where the extensive use of water, energy and chemicals required during the manufacturing processes as well as the generation of waste and emissions emitted during the production and transportation stages result in a significant environmental footprint. On the other hand, due to the already cited trends of globalization and outsourcing to the developing countries, social scandals in fashion supply chains have become common occurrences, including child labor, safety issues, forced labor and low wages. Given the dependence on suppliers, it is not enough to implement sustainability strategies pursuing an organizational logic. Sustainability goes beyond organizational boundaries [25]; therefore, it is fundamentally needed to pay attention to the relations throughout the supply chains. That being said, it is vital to spread sustainability across supply chains [26] by pursuing rather collaborative approaches $[27,28]$.

Sustainable supply chains require transparency [29], and transparency in supply chain information is growingly demanded [30]. Even though companies are expected know about their supply chains, prior research, however, indicates a lack of transparency about lower tier suppliers [31]. Transparency 
is not easy to ensure and enhance, especially for those industries having globally dispersed supply chains. Indeed, the embedded complexity of the supply chains leads to a lack of visibility for the brand owner which then results in low performance in terms of public disclosure [32]. Supply chain transparency is minimal in the fashion industry; yet, it is pivotal to ensure [33] for which collaborative relationships with the suppliers appear to be strong antecedents [34].

This study is positioned at the connection between supply chain management and sustainable operations literatures. It pursues an exploratory and anthropological approach by setting its context as the fashion industry. From an interdisciplinary background, the study adopts theoretical constructs to investigate how and to what extent supply chain relations, power use and collaborative actions, in the broader supply chain setting, can influence transparency. By doing so, it also aims at being one of the few contributions to underline the impact of NGOs in facilitating this process. Specifically, the twofold objective of this article is to understand the way by which brands form collaborative relationships in order to enhance transparency and to explore how NGOs can facilitate this process. The article adopts the relational view as the guiding theory while undertaking three theoretical constructs to fully explore fashion supply relations and conducts an exploratory case study including an internationally acknowledged fashion group and an important NGO on fashion transparency. Results reveal that supplier engagement, commitment and leadership appear to be antecedents in order to enhance supply chain transparency while, at the same time, NGOs are observed proactively pushing companies to disclose more information about their supply chain operations. The rest of this paper is organized as follows. Firstly, Section 2 channels the theoretical background, where the relational theory is explained and the knowledge about the adopted theoretical constructs is addressed. Subsequently, the research questions are reported, reflecting the research gaps emerged during the literature review phase. In Section 3, the methodology employed for the empirical analysis is given. Section 4 encapsulates the findings of the case study conducted together with a discussion of the outcomes obtained. Finally, Section 5 encompasses some final considerations, limitations and possible future avenues for further research.

\section{Literature Review}

\subsection{Relational Theory}

Various theoretical perspectives have been adopted to investigate SSCM practices and stakeholders' involvement in them [35]. To illustrate, the stakeholder theory, one of the most frequently used theories, argues that a company has responsibilities for a wide range of stakeholders, including shareholders, customers, employees, as these stakeholders both affect and are affected by the company's actions [36]. Another important theory, the resource-based view (RBV) indicates that competitive advantage is closely linked to a company's resource base [37]. Although the RBV is useful to understand how a firm reaches above-normal returns, it underestimates the fact that (dis)advantages of a firm are usually related to the (dis)advantages of the network of relationships in which the firm operates [38]. It therefore falls short in explaining how firms gain competitive advantage in network environments where firms maintain multiple collaborative relationships with alliance partners. RBV has been extended into the state of natural resources (natural-resource based view) [39] and supply chain relations (the relational view) [40].

The relational view takes an inter-organizational perspective and views the linkages between firms as the sources of competitive advantage [23]. Having extended beyond the RBV, the focus of relational view is on the relationship with other firms within the supply chain rather than looking at the internal capabilities and resources of the firm. For this reason, this theory is adequate to investigate the sustainability driven collaboration implemented amongst supply chain actors. According to the relational view, resources and capabilities are more valuable when combined in unique ways, resulting in an advantage over competitors unable or unwilling to do the same. In this view, developing 
a competitive advantage is about generating relational rents, supernormal profits jointly created in the relationship which cannot be developed by firms in isolation [38].

Four main sources of relational rents include:

- Investment in relations specific assets (site specificity, physical asset specificity, human asset specificity) representing economic barriers for new entrants;

- Investment in knowledge sharing which result in a sustainable advantage for the actors which are sharing it, due to the incapability of competitors in imitating this process;

- Complementary resources and capabilities which guarantee higher firms' performances through synergies exploitation at a lower cost;

- Effective governance mechanisms based on self-enforcing agreements allowing to minimize transaction costs and strengthen the partnership relation.

The aim of these rents is to move away from arm's length market relationships in which all competitors can easily duplicate that relational typology, as there is nothing unique about an arm's length interaction established between the partners. In particular, there are factors that can influence the outcomes in terms of relational rents, which can be grouped and named as the relational capital, including mutual trust, communication, incentives alignment, relationship history, commitment, and absorptive capacity during knowledge transfer [23,27]. In this direction, relational rents are difficult to imitate, as competing firms not only encounter difficulties in finding a partner with the requisite complementary strategic resources but also have difficulties to access the needed capabilities since these show a specific path dependence.

\subsection{Collaboration}

Since consumers, and stakeholders at large, do not differentiate between the supply chain actors, it is the brand owner that is deemed liable to extend sustainability along the chain [41]. Broadly speaking, when a buying firm encounters shortcomings in its suppliers' sustainability performance, it can either invest resources in order to increase performance or look for alternative suppliers [42]. Sustainable suppliers appear to be a scarce resource, so firms tend to prefer the first option. In fact, it is difficult for the buying firm to find suppliers with an appropriate level of awareness regarding the management of environmental and social issues that can, at the same time, match the quality standards required for materials [27].

Two practices useful to enhance suppliers' sustainability performance are given by assessment and collaboration. The former typically relies on power, while the latter on trust. Assessment (monitoring and evaluation) generally aims at controlling suppliers' outputs with respect to specific performance criteria through the means of questionnaires, non-regulatory standards or audits [42]. Supply chain collaboration constitutes a partnership process in which no less than two independent parties work together for the fulfilment of common goals and mutual benefits. Collaboration can be either vertical, with suppliers and customers, or horizontal, with competitors and third parties like NGOs [37]. An attempt to address supply chain collaboration for sustainability in its broad perspective is the one of Chen et al. [37] that provides a framework classifying the typologies of collaborative relationships.

Collaborating with suppliers generally consists of training and education practices as well as of financial support aiming to jointly improving the sustainability performance. In order to achieve a sustainable value chain, both assessment and collaboration are needed, as they are positively associated $[43,44]$ However, the way in which a relationship can move from the burden of compliance to a more collaborative context needs to be further investigated [45]. Factors that appear to be supporting the establishment of a collaboration consist of trust, commitment, complementary resources and capabilities, and investment in supplier development activities [27]. While, the buying firm's leadership/power seems not essential to reach an advanced sustainability level [46].

In global and fragmented industries, like fashion, where there is a high level of outsourcing to developing countries, collaboration emerges to be a fundamental aspect to spread sustainability. 
However, collaboration activities in this direction still deserve to be advanced, meaning that firms should extend sustainability across the entire chain. As previous research reports, fashion brands can adopt several strategic approaches to sustainability, according to the importance given to these matters. Nevertheless, it requires a holistic commitment, that is, a buyer could be proactive in adopting social and environmental practices, but unless its suppliers are interested in sustainability, it is possible that any sustainability effort could be futile [47]. Furthermore, involving NGOs and trade bodies can facilitate the collaboration by sharing knowledge and resources. However, the role of NGOs, in terms of contribution to benefits generation and trust and commitment enhancement requires further investigation [23,48]. In particular, there is little known about social sustainability [37], stressing the shortage of researches exploring how supply chain collaboration can improve social sustainability.

\subsection{Power Distribution}

Power in supply chain relationships is the ability of one firm to influence another firm [49]. A main driver leading firms to extend sustainability is represented by the stakeholder pressure [28]. In accordance with the institutional theory, three driving forces include normative (e.g., customers and NGOs), coercive (e.g., government) and mimetic (e.g., depending on competitor initiatives) pressure. Prior research related to the stakeholder pressures have somehow mixed and conflicting results. This occurs due to the fact that companies pass through different evolutionary stages during their sustainability journey, ranging from being non-adopters to full adopters [46]. In particular, it emerges that government pressure remains high throughout the evolutionary path, while the pressure coming from the consumers becomes crucial moving towards the full-adopter phase. Among these aforementioned pressure categories, it is worth exploring the NGOs' role. Even though their influence seems to have no effects [50], scholars perceive that this result might not in line with reality. Therefore, the changes initiated by the forms as a result of this pressure represents a rich research opportunity [35].

As regards customer pressure, there is an influence exerted by the customers as an essential driver that motivates firms to begin and sustain the SSCM development process [51], but it requires an effective sustainable process management (internal practices). The direct relationship between the customer pressure and sustainable supply management (external practices, like assessment and collaboration) is fully mediated by a sustainable process management. Concerns coming from external stakeholders are generally moved toward the suppliers. In fashion supply networks, the relationship between a brand owner and its suppliers is usually characterized by power asymmetry, given that a supplier usually serves one major buyer, which in the majority of cases is a large fashion group. Therefore, no matter which is the level of supplier motivation in developing sustainable practices, a low interest coming from the focal company will lead to a basic level of adoption of external sustainability practices [47]. In the fashion industry, stakeholders' pressure, especially the one exerted by NGOs and media, turns out to be really relevant as a driver [33]. However, it is not enough to concentrate on incentives coming from the external actors; as much more interest should be paid to the capability of companies to react on the eventual consequences of their suppliers' management approaches.

\subsection{Transparency}

Transparency is making sustainability information available to the public [52]. In the context of corporate accountability, transparency refers to the ability not only to "know internally" that firms are exercising diligently, but also to "show externally" that this is really the case [53]. Concerns relating to the use of forced or child labor, health and safety conditions, and living wages are gradually resulting in stakeholders calling for more visible and transparent corporate practices. Therefore, keeping the secrecy of corporate wrongdoings has become extremely risky [54]. Transparency is seen as a means towards sustainability improvements rather than a mere end [53].

A company is considered transparent when it publishes the names of specific suppliers, their sustainability conditions and relevant purchasing practices related to each of them [32]. By moving forward, a more holistic definition is provided, which also includes the disclosure of sustainability 
impacts, policies and commitments, sustainable actions undertaken and their relative effects [53]. In recent years, fashion brands have responded to public sustainability campaigns, such as Fashion Revolution's Transparency Index. However, companies seem to be reluctant to move beyond basic disclosure toward increased transparency [55]. In this vein, it becomes evident that even though there are noteworthy efforts to increase corporate sustainability at large, there has been less progress related to SC transparency [14].

Consumers' trust can only be regained through open communication and information, and transparency is becoming a fundamental issue within the fashion industry. Stakeholders consider the "made in" attribute less relevant than the "made by", which requires a lot of information to be gathered about manufacturing stages. This activity is, however, really challenging since production processes are fragmented across several countries throughout complex supply chains. Despite prior contributions into the state of supply chain transparency in the fashion industry [5,11,56,57], fashion's transparency performance is still low in comparison with what is required by the stakeholders, underlying that both research and practice are needed to enhance transparency in fashion supply chains.

Transparency and traceability have always been problematic in and across global supply chains; however, research shows that innovation and technology is gradually utilized to enhance transparency. Blockchain technology is being applied across various industrial settings, for example in maritime shipping supply chain to enhance efficiency and improve visibility [58], and in rental service platforms to disclose product information to the customers [59]. Furthermore, some fashion companies adopt technological tools to enhance transparency within their supply networks. Hugo Boss is using the blockchain technology in their cotton supply chain. Similarly, Everledger tracking and tracing the authenticated source of diamonds has encrypted the source of more than 2 million diamonds since 2015. What emerges is that transparency and traceability solutions, including the blockchain technology, requires strong organizational and supply chain capabilities such as collaboration, governance of these efforts and leadership [60]. It is therefore crucial to understand how the supply chain dynamics pertaining to collaboration, power use and supply chain relations could be established and coordinated to inspire, guide and implement mechanisms (technology-driven or human-driven) in and across supply chains to enhance transparency. The next section translates all knowledge gaps encountered in the extant literature into formulated research questions followed by the explanation of methodological steps taken throughout the study.

\section{Methodology}

\subsection{Research Objectives}

This section summarizes abovementioned theoretical gaps and translated them into research questions for providing knowledge contributions. The majority of existing research addresses the way in which supply chain collaboration among actors can enhance the environmental dimension of sustainability with little known about the way in which collaboration can guarantee a higher level of social sustainability along the chain. In particular, there is a need for more empirical evidence to link the fields of collaborative networks and social sustainability, especially transparency [32]. A growing concern for transparency in fashion supply chains represents an unexplored area of research. To date, studies have focused on providing a comprehensive transparency definition with little known about how a brand can enhance the level of transparency along its supply chain. To this end, this study aims to explore:

RQ1. If, how and to what extent does a brand form collaboration with other supply chain actors in order to enhance transparency?

Different studies have investigated the importance of stakeholder pressure as a driver for sustainability implementation along the chain, arriving at opposite outcomes. In particular, among the external stakeholders calling for brands for increased transparency is NGOs that deserve a particular interest. Given the research gap about the role and actions of NGOs in inducing brands to extend 
sustainability, there is a knowledge gap on the role of NGOs for leveraging supply chain transparency. Hence, the second question is formulated as:

RQ2. If, how and to what extent do NGOs influence the brand to enhance transparency?

It is not enough to explore which are the actions undertaken by NGOs in order to push brands disclosing information. It is indeed more interesting to investigate the effects of this influence on buyer-supplier collaborative relationships. In fact, it is not ensured that there exist implications of NGOs actions on supply chain collaboration process, and that this could lead the brand to advance the level of collaboration through an improved partnership with the suppliers. In this sense, there is no guarantee that the eventual collaboration decisions undertaken by the brand in response to the NGO pressures have a long-term orientation. Therefore, this study asks:

RQ3. If, how and to what extent does the NGOs influence affect the collaboration between the brand and the supply chain actors?

\subsection{Methodology Justification}

Qualitative research is different from quantitative research on the basis of entirely different philosophical beliefs. A case study is an empirical inquiry exploring an on-going phenomenon within a real-life context. It is adopted when a how or why question is asked about a contemporary set of events over which the investigator has little or no control [61]. Accordingly, since this study aims at fully exploring practices that a fashion brand implements in order to build a sustainable collaboration with suppliers to improve transparency, and at understanding how this process is influenced by external actors, the case study method is deemed adequate and subsequently adopted. Furthermore, a case study approach is the best option to explore collaboration when dealing with complex relational and social aspects, as it allows to capture the dynamics behind the system [48].

By studying a phenomenon in a specific context, the findings of a case study provide insights into how the phenomenon actually occurs in a given situation. This intrinsic methodology characteristic provokes criticism concerning the wider contribution that the findings can generate. Typical complains deal with the lack of outcome generalizability and objectivity. However, a case study has the objective to understand and to theorize by generalizing to theoretical propositions and not to populations [62]. Case research indeed turns out to be one of the most powerful methodology for the new theory development [63]. This study opts to investigate a case to cover both the phenomenon and the context in order to generate a number of operational steps. That being said, this study adopts the case study method by using interviews and observations to gather information to obtain and examine detailed knowledge in order for capturing the so called "lived reality" [37].

\subsection{Case Selection}

As reported earlier, this study is positioned at the connection between supply chain management and sustainable operations literatures. By pursuing an exploratory and anthropological approach, it investigates sustainable supply chain management and transparency in the context of fashion. Exploratory cases seek to explore any phenomenon by investigating general questions, which are meant to open up the door for further examination of the phenomenon observed. It actually results the best method to be applied when exploring new frameworks and mechanisms relevant to under-studied research topics, as in this article [64]. This article opts for a single case to increase the depth of the analysis regarding common practices and actions. This mainly because little or nothing is known, especially in the fashion sector, about the way collaborative activities can lead to enhanced transparency and about the way NGOs' actions facilitate this enhancement. A case capable of shedding light on the themes under investigation is a project named as "Fashion Transparency". The main actors involved represent a fashion group and an NGO. 


\subsection{Sample Selection}

The organization picked for NGO is Fashion Revolution. The company under investigation is Group 1. Group 1 is an influential company, owning a portfolio of roughly thirty major fashion brands. The group is well known for its strong commitment to sustainability. In particular, Group 1 brands are indeed some of the few fashion brands showing quite strong results in terms of supply chain transparency. To illustrate, Brand $\mathrm{T}$ is one of the signature brands of Group 1. In order to provide further evidence and illustrations in terms of how supply chain information is disclosed, e.g., commitments, actions and so on, this study specifically analyses the supply chain information that belongs to Brand $\mathrm{T}$ and that is reported by Group 1.

Fashion Revolution, on the other hand, has been chosen due to their dedication and influential work on supply chain transparency, resulting in a growing number of brands disclosing supply chain information publicly. Fashion Revolution is a global movement created in 2013 in response to the Rana Plaza disaster happened in Bangladesh on 24 April of that same year. Since 2016, Fashion Revolution adopts an index called "Fashion Transparency Index", which scores and ranks the biggest global fashion and apparel brands based on the information disclosed to stakeholders. The index takes into account five key performance areas: Policy \& Commitments; Governance; Traceability; Know, Show \& Fix; Spotlight Issues. Each area and associated questions to investigate the companies' transparency performance are summarized in Table 1.

Table 1. Fashion Transparency Index Performance Categories.

\begin{tabular}{|c|c|c|c|c|}
\hline Policy \& Commitments & Governance & Traceability & Know, Show \& Fix & Spotlight Issues \\
\hline $\begin{array}{l}\text { What are the brands' } \\
\text { environmental and social } \\
\text { policies? }\end{array}$ & $\begin{array}{l}\text { Is there board level } \\
\text { responsibility for the } \\
\text { company's social and } \\
\text { environmental impact? }\end{array}$ & $\begin{array}{l}\text { Does the brand publish a } \\
\text { list of its suppliers, from } \\
\text { manufacturing to raw } \\
\text { materials level? }\end{array}$ & $\begin{array}{l}\text { How does the brand assess } \\
\text { implementation of its } \\
\text { supplier policies? }\end{array}$ & $\begin{array}{l}\text { What is the brand doing to } \\
\text { address issues like gender } \\
\text { equality and female } \\
\text { empowerment? }\end{array}$ \\
\hline $\begin{array}{l}\text { How the brand put its policies } \\
\text { into practice? }\end{array}$ & $\begin{array}{l}\text { Can a relevant person or } \\
\text { department be easily } \\
\text { contacted for doubts? }\end{array}$ & $\begin{array}{c}\text { If so, how much detail do } \\
\text { they share? }\end{array}$ & $\begin{array}{l}\text { How does the brand fix } \\
\text { problems when found in } \\
\text { its supplier facilities? }\end{array}$ & $\begin{array}{l}\text { What is the brand doing to } \\
\text { support Freedom of } \\
\text { Association and the } \\
\text { payment of living wages? }\end{array}$ \\
\hline $\begin{array}{l}\text { What are the brand's future } \\
\text { goals to improve its impacts? }\end{array}$ & & & $\begin{array}{l}\text { How can workers report } \\
\text { grievances? }\end{array}$ & \\
\hline
\end{tabular}

To illustrate, Group 1 can be characterized by an interesting growth path from 2017 to 2019, as its final score jumped from $24 \%$ to $57 \%$. In particular, by looking at 2019 final scores of the 200 biggest global fashion brands assessed, Group 1 scored $57 \%$ while the best in class resulted as $64 \%$.

\subsection{Data Collection}

The primary source of data was semi-structured interviews supported by conversations and observations made during industrial engagement events. The interview protocol can be seen in Appendix A. As for the interviews, the interviewees involved are the CSR Sustainability Coordinator for the EMEA market of Group 1 and the Country Coordinator of Fashion Revolution Italy. The research protocol was developed in accordance with the theoretical constructs elaborated above. In addition to personal interviews of around 40 minutes each, data was collected using secondary sources, such us sustainability reports, corporate documents and online coverage, allowing, therefore, to strengthen the overall findings $[62,63]$.

\subsection{Data Analysis}

To ease the analysis process, the available reports were downloaded and converted into PDF format, while the interviews conducted were transcribed in Word files. The first phase of the data analysis was the coding. In particular, by reading the various documents, most relevant parts were highlighted and 
then reported. This was organized according to the source origin, namely company-related documents or NGO-related documents. The output of this first analysis step was refined by extrapolating the most relevant codes and eliminating duplicates. After having read multiple times the list containing the resulting codes, they were grouped in categories according to common patterns spotted. The last phase of data analysis consisted of the extraction of themes. Essentially, starting from the categories, the same approach was adopted. Accordingly, the content was distributed among three main themes, each one being respectively linked to one of the three theoretical constructs under investigation, namely collaboration, influence and transparency.

\section{Findings and Discussion}

\subsection{Enhancing Transparency}

During the 2000's, some of the brands of Group 1 were among several apparel companies accused of using child labor in their supply chains. Since then, the progress towards social sustainability and transparency has been made, which makes Group 1 one of the pioneers of sustainability. Nowadays, the group holds itself accountable for what goes into their products as well as for how these products are made. This is exactly what consumers want, and the group is more aware and wants to do business with manufacturers they can trust. They increasingly look at transparency and sustainability credentials of their suppliers before making a purchase. Group 1 is one of the brands trying to be more open with the customers by using their website to share data about corporate sustainability and by inviting people into the conversation. These data enable people to draw their own conclusions, supporting what is stressed earlier [56], that is, transparency is beneficial because the public can monitor and see the real issues across supply chains. Group 1 believes that there is nothing to hide and therefore it adopts transparency as one of their guiding principles. To illustrate, Brand T was selected to report some of the information disclosed. Extensive quarterly sustainability reports are among the steps taken by Brand $\mathrm{T}$ towards progress on supply chain information disclosure.

By examining the information disclosed by Brand $\mathrm{T}$, some patterns emerge and are categorized in accordance with transparency dimensions supported by Fashion Transparency Index.

- Traceability: Brand $\mathrm{T}$, as well as other Group 1 brands, provides visibility into the state of supply chain issues and risks, which are mainly concentrated at raw material stages. Indeed, the aim is to ensure the responsible material sourcing by tracing them back to the origin. For example, factory information is disclosed, and supply chain sourcing map is provided.

- Purchasing practices: Brand T, as well as other Group 1 brands, gives information related to the various sustainable practices adopted during the sourcing phase. For example, further information is given about the fact that cotton grown in a sustainable manner is purchased and tanneries that are compliant with the leather working group's assessment methodology are partnered with.

- Commitment: Brand T, as well as other Group 1 brands, reports sustainability targets that is committed to achieve. For example, targets include VOC reduction targets, the increased use of ROR materials, PVC free production, and the increased use of renewable energy.

- Actions: Brand T, as well as other Group 1 brands, not only discloses the targets to reach but also provides actions and best practices to be shared.

- Effects: Brand T, as well as other Group 1 brands, ensures exhaustive awareness to their customers, therefore the brand describes the effects that disclosure decisions undertaken have on the environment and on the society.

By disclosing the supply chain information, in the form of supplier list and online traceability maps, Brand $\mathrm{T}$ has demonstrated that materials are sourced in a responsible manner, respecting global human rights and avoiding deforestation. Transparency also helps Brand T, and consecutively Group 1, to evidently address that substituting solvent-based adhesives with water-based alternatives lowers the environmental impact while improving working conditions in factories. Further, Brand T quantitatively 
shows how using organic cotton reduces the amount of water and chemical use, which is directly linked with farmers' health and safety as well as ecological footprint. Through the use of certifications, Brand $\mathrm{T}$ also ensures that the leather purchased is processed by using environmental best practices and performance in all areas of production, from chemical, water and waste management to energy use and traceability. By analyzing the last release of the brand's sustainability report, it has been possible to extrapolate some supply chain information disclosed, which is summarized in Table 2.

Table 2. Information Disclosed by Brand T.

\begin{tabular}{|c|c|}
\hline Disclosure Category & Information Shared \\
\hline Factory disclosure & The name, geographic location and SC stage is disclosed for all active factories \\
\hline $\begin{array}{l}\text { Target of average grams of volatile } \\
\text { organic compounds (VOCs) }\end{array}$ & $\begin{array}{l}\text { Solvent-based adhesives release VOCs. Disclosing chemical consumption allows } \\
\text { to target high VOC-content materials for reduction, substitution or elimination }\end{array}$ \\
\hline Actions to reach the VOCs target & $\begin{array}{l}\text { Through engineering reviews, the use of water-based adhesive is promoted, } \\
\text { in order to facilitate VOCs reduction efforts as well as maintaining the } \\
\text { quality and physical integrity of products }\end{array}$ \\
\hline $\begin{array}{l}\text { Commitment to purchase cotton } \\
\text { grown in a sustainable manner }\end{array}$ & $\begin{array}{l}\text { Brand T has the goal of having } 100 \% \text { of the cotton used in apparel, accessories } \\
\text { and licensed goods to be sourced more sustainably than conventional cotton }\end{array}$ \\
\hline $\begin{array}{l}\text { Sustainable tanneries for leather } \\
\text { purchase }\end{array}$ & $\begin{array}{l}\text { All leather suppliers are audited according to protocols established by the Leather } \\
\text { Working Group (LWG). Performances are scored on a scale of Audited, Bronze, } \\
\text { Silver and Gold. Brand T is committed to source from tanneries with Silver } \\
\text { or Gold score }\end{array}$ \\
\hline $\begin{array}{l}\text { Commitment to increase the usage } \\
\text { of recycled, organic and renewable } \\
\text { (ROR) materials in footwear }\end{array}$ & $\begin{array}{l}\text { Brand } \mathrm{T} \text { has product development strategies for increasing the use of ROR } \\
\text { materials, which represent environmentally preferred materials }\end{array}$ \\
\hline Actions to reach the ROR target & $\begin{array}{l}\text { Brand } \mathrm{T} \text { has developed design policies that require ROR content in all new } \\
\text { product development and has the objective to revise carry-over styles to engineer } \\
\text { in ROR where possible }\end{array}$ \\
\hline $\begin{array}{l}\text { Commitment to produce items that } \\
\text { are } 100 \% \text { PVC-free }\end{array}$ & Brand T is committed to look for and utilize PVC alternatives for items production \\
\hline Actions to reach PVC target & $\begin{array}{l}\text { Actions consist in seeking PVC-free materials and reviewing materials and } \\
\text { manufacturing equipment updates to guarantee PVC reduction }\end{array}$ \\
\hline $\begin{array}{l}\text { Commitment to have non per } \\
\text { fluorinated compounds (PFCs) }\end{array}$ & $\begin{array}{l}\text { PFCs are chemicals found in durable water repellent (DWR), a coating added to } \\
\text { fabrics to make them water-resistant }\end{array}$ \\
\hline Actions to avoid PFCs & $\begin{array}{l}\text { Brand T has the goal to identify non-PFC chemistry innovations which can } \\
\text { guarantee the performance attributes required by products }\end{array}$ \\
\hline $\begin{array}{l}\text { Commitment to increase the usage } \\
\text { of renewable energy and improve } \\
\text { the waste diversion rate }\end{array}$ & $\begin{array}{l}\text { To protect natural resources, Brand T looks at applying best practices from the } \\
\text { parent company's zero waste facility }\end{array}$ \\
\hline Vendor selection pre-screening & $\begin{array}{l}\text { When considering new factories, social compliance performance is an important } \\
\text { aspect. This is ensured by having factories that provide evidence of their } \\
\text { performance by way of recent audits by other brands, external monitoring firms, } \\
\text { or social certificates }\end{array}$ \\
\hline Supply chain sourcing map & $\begin{array}{l}\text { Brand T, along with other Group } 1 \text { brands, has a full SC footprint map for one of } \\
\text { its most iconic products. It displays the number and locations of suppliers in a } \\
\text { region and users can zoom in for a close-up look at each supplier, including info } \\
\text { about onsite inspections, verifications and associate interviews }\end{array}$ \\
\hline $\begin{array}{l}\text { Service actions undertaken by } \\
\text { volunteer employees }\end{array}$ & $\begin{array}{l}\text { Brand } \mathrm{T} \text { discloses information related to the hours served by employees and the } \\
\text { number of events dedicated to the community wellbeing }\end{array}$ \\
\hline
\end{tabular}

Nevertheless, the greatest difficulty associated with transparency that Group 1 is facing is none other than the supply chain complexity, supporting the earlier argument [65]. In particular, by moving upstream in the chain, the number of actors to consider exponentially increases without a clear and visible roadmap to pursue. "One day we made an analysis of one specific jacket and we traced the entire SC: we ended up seeing that we have more than 100 suppliers just for one jacket. Actually, the size and the complexity of how the textile industry has been set up are actually the biggest barrier. If your Supply Chain is 
made out of thousands of suppliers and each supplier has its own challenges, this is what makes difficult to be 100\% transparent" addresses the CSR Sustainability Coordinator for the EMEA market of Group 1.

What emerges is that supplier engagement is essential to address complexity and increase supply chain visibility. In line with that, Group 1 is working to transform supply chain relationships, moving from conventional transactional exchanges towards partnerships. Supply chain complexity is a common industrial problem in the fashion industry; yet, Group 1 is among the few companies aiming to fully address it. To illustrate, a dedicated team (the Responsible Sourcing team) is constantly in touch with the suppliers to support them through capacity development programs.

The relationships established have a long-term orientation, as Group 1 tends to avoid using a supplier just for a single season or for a limited period of time. "What we do with our suppliers is to create long term collaborations. Normally, we are not using a supplier only for one season. The idea is to keep our supplier for a longer period. How do we create this relationship? It requires long term thinking" adds the CSR Sustainability Coordinator for the EMEA market of Group 1.

This long-term collaboration follows a plan specifically developed to ensure continuous improvement. A prerequisite for a collaborative relationship lies in the supplier selection process [2]; hence, Group 1 demands evidence in terms of a potential supplier's sustainability performance. Financial aspects are overshadowed by social and environmental sustainability during this evaluation stage, and once selected, the suppliers are subject to continuous monitoring and control procedures; as an instance, every facility involved in the manufacturing (cutting facilities, sewing plants, screen printers, embroiderers, laundries and packaging locations) of Group 1-branded products is periodically monitored to verify their compliance. This constant work is essential for the group to gain visibility with an aim of ensuring a fair, safe and non-discriminatory working environment at supplier facilities. This outcome is line with [42] stating that assessment is a necessary prerequisite for collaboration. In addition to periodically performed audits, extra audits can also be carried out when there is a specific situation about a supplier facility. For instance, part of ensuring an ethically responsible working environment needs that employees can report any concern regarding potentially unethical activities by using a grievance system taking place at each supplier facility. This grievance system allows the workers to feel empowered to shed light onto some social or environmental issues that may need greater attention. To regularly communicate the expectations, suppliers are continuously engaged with the group activities, including meetings, traceability and verification checks, and quality controls. For those suppliers that need support to meet the requirements, Group 1 provides guidelines and support through a creation of remediation activities. Support offered includes training, development, technical assistance and financing, where needed. Therefore, it can be described as a hand to hand approach whereby every time when Group 1 has certain issues, it engages with their suppliers to ensure not only the compliance but also the improvement. Nevertheless, suppliers need to demonstrate a certain level of commitment towards sustainability to get access to this support [51].

For a focal company is not easy to reach sub-suppliers across lower tiers to gather information and influence them to drive change towards enhancing transparency. Due to supply chain complexity, this attempt is hindered and moving further upstream becomes more and more challenging. Group 1 has visibility on all tier 1 suppliers as well as on the majority of tier 2 . The way in which the group reaches further sub-suppliers depends on different aspects, such as the brand, the product and the supply chain structure. Generally, dealing with suppliers is necessary to arrive at sub-suppliers. Certain suppliers, like the ones located at tier 1, are exclusive to Group 1. Therefore, with most of them the company has a really strong relationship based on trust, which represents a strong enabler to gain visibility. Additionally, differently from what was declared by [46], being a large (and influential) player makes things easier. Group 1 exerts a big leverage on suppliers. However, Group 1 uses their expertise and influence to reach sub-suppliers and, therefore, to engage them through joint resolution techniques to the end of enhanced transparency. In this way, it becomes possible to obtain and verify information to disclose supplier lists and supply chain sourcing maps. "It's really "let's sit together and see how we can help you make this happen". The more we are committed to them, the more they are 
committed to us. It' a two-way relationship" illustrates the CSR Sustainability Coordinator for the EMEA market of Group 1.

Every year, the corporation enlarges the pool of suppliers to be engaged through collaborative actions. For example, Group 1 is now trying to expand the pool of products that are completely traced (the number is currently 9 but the goal is to increase the number of totally traceable products up to 40). Undoubtedly, it will be practically impossible to ensure that without the involvement of the suppliers. It is also challenging to ensure this for all product models. For this reason, at the initial stage, products that are more relevant for the customers are chosen. However, at the same time, Group 1 is truly committed that, regardless of the traceability status, all products are, and will be, made in more transparent and sustainable ways. By leveraging on the strong relationships that Group 1 has with the majority part of the suppliers, the objective is to institutionalize traceability as a best practice within their global supply chains. In this way, as mentioned, factory disclosure could really become a means to elaborate new standards and shared solutions, helping to advance sustainability conditions in across the chain.

To address and ensure sustainability at lower tier supply chain stages, Group 1 makes a large use of policy documents. Through policies, the company ensures that raw materials are sourced from those that are committed to the use of environmentally responsible methods, respecting human and animal rights, and maintaining traceability within their supply chains. Group 1 has policies in terms of animal derived materials, forestry derived material and conflict minerals. These are able to guarantee that certain components and certain materials are actually not present in the final product. To illustrate, leather is no longer purchased from Brazil to help preserve the Amazon forest.

To deal with the supply chain complexity and with the limited direct control the group has on upstream actors, Group 1 collaborates with other actors, such as industry peers, working groups, academia, government agencies and NGOs by pursuing a multi-stakeholder mechanism. These actors are able to identify possible improvements thanks to their localized knowledge. The company leverages on the existing partnerships with them in order to develop policies and programs for assuring that products come from factories that certainly meet the strong compliance principles. Suppliers that are using recognized third-party certifications are qualified. For instance, Group 1 works with Better Cotton Initiative (BCI) to source cotton and supports BCI by giving funds to support them to establish on-field relationships with the farmers. Similarly, when it comes to leather, the group asks their tanneries to be compliant with the Leather Working Group (LWG) specifications.

Supplier engagement and supply chain collaborations are fundamental to reach sustainability targets (reduction of emissions, reduction of materials impact and so) and to enhance transparency at large. Commitment, in this vein, appears to be a strong antecedent to enhance sustainability through joint actions. Additionally, Group 1 engages the suppliers on topics such as renewable energy, climate change, chemicals and traceability and helps them to get access to funds that eventually empower the supplier communities. For instance, one of the group goals is to help 2 million people in their supply chain by 2030 through a number of development programs dedicated to suppliers, aiming to enhance well-being as well as health.

\subsection{NGO's Influence}

Consumers demand sustainability [66] and transparency [57], and, consequently, a wide range of industries, including electronics [34], apparel and footwear such as fast-fashion [31] and luxury [24] are gradually paying attention to transparency. Yet, fashion, in particular, is a secretive business [17] that has fragmented and complex supply chains [13]. In this challenging industrial setting, supply chain transparency is not fully addressed. To bring the operational stages under the spotlight, the public is growingly raising their voice to provoke companies to open up about their supply chain stories. Fashion Revolution, founded in 2013, (www.fashionrevolution.org) is one of the most profound NGOs requiring fashion companies to disclose supply chain information. "Consumers have the right to 
know where and how a garment has been made and if, during the manufacturing, people and planet have been safeguarded", states Fashion Revolution.

Fashion Revolution works closely with the consumers through several engagement and awareness increasing activities. Fashion Revolution therefore exerts an indirect influence on firms, mediated by the consumers. By being engaged into the conversation, the consumers feel empowered and demand information by asking one essential question: \#whomademyclothes. Fashion Revolution creates advanced awareness through multiple loops of learning, and, consequently, the consumers use their voice to influence the brands, signaling a collective bottom-up approach. Responding the research gap [55], it becomes apparent that NGOs do have the leverage to enhance transparency by empowering the final consumers.

Particularly, Fashion Revolution creates tools, recommendations, publications and engagement events to increase knowledge about sustainability performance of the fashion brands. By doing so, it creates an open as well as transparent platform on which everyone can act upon the solution. The consumers ask questions, demand information and pressure the companies to disclose more information about their supply chains. The approach adopted by Fashion Revolution is based on communication and education. It mainly consists of organizing and/or taking part in sustainability events, conferences and conventions and of creating events with the students at their schools. Through direct engagement, it becomes evident that they increasingly communicate and spread the message, resulting in higher awareness and stronger demands. The first message the NGO wants to convey is that the consumers have the opportunity to vote with their money for the world they desire by choosing what and where to buy. This aspect is at the base of the systemic change aimed by Fashion Revolution. Customers could and will choose those brands publishing supply chain information such as where clothes are produced, what materials are used, if there are certifications related to the fabric origin, if human rights are respected across the chain and if fair wages are taking place.

The main tool provided to the public in order to learn about transparency and sustainability actions undertaken by fashion companies is the "Fashion Transparency Index". Every year, a comprehensive set of questions are sent out to fashion companies. Then, the Fashion Revolution team aggregates all this collected information and performs their bespoke methodology to analyze the data in order to come up with a final score. Every year, fashion companies are ranked based on their supply chain disclosure and the Fashion Transparency Index indeed depicts a picture about who is more transparent and who is not. In this way, by visiting Fashion Revolution website, the public becomes aware of who is doing what. Furthermore, this represents rather an opportunity than a pressure, as such, fashion brands can in fact have the opportunity to share information required by consumers while understanding the weak areas where their performance must get improved. This outcome is in line with the earlier findings [67] addressing that NGOs can be seen as a source of opportunity that companies can learn from rather than a source of risk that can damage the company. "We tell our followers that it is very important to be in touch with their favorite brands and to write to them, posting on social media direct requests towards companies saying "I love your brand, I would like to buy it, but I would like to know more about where and how your clothes are made". Now we have access to customer services of every brand. You have to keep in touch with the brands to show that you care, and you have the right to ask for more information" explains the Country Coordinator of Fashion Revolution Italy.

Moreover, the index enables the companies to find out where to focus, as in the case of Group 1, and where to improve from a communication perspective. To illustrate, Group 1, despite having a strong function dealing with sustainability through ad hoc action plans, was not always able to communicate the commitments as well as the achievements. Therefore, Fashion Transparency Index has been a good tool whereby an industrial benchmark enabled the group to understand how other industrial players communicate decisions and actions in a better way. Coherently with what was addressed previously [41], Fashion Revolution does not make distinction among brands, as all brands are considered equally responsible regardless of their size and the strategic importance of their products. 
Fashion Revolution encourages the consumers to have a direct contact with the companies by using social media and customer services through which people can directly request information from their favorite brands about how and where their clothes are made. Therefore, the NGO role is mainly teaching and guiding people about which questions to ask and how to deal with them. By receiving a lot of transparency inquiries, companies start realizing that they need to provide answers and that there is a strong tendency among young consumers toward sustainability. "Consumers can go to our website and see the transparency index to know exactly who is doing what. This is one of the tools. We like to consider this an opportunity for a company rather than a pressure" states Country Coordinator of Fashion Revolution Italy and adds "Companies that do not want to disclose information about their supply chains, I could imagine they have some kind of little secrets to hide".

The desire to buy something made by pursuing ethical principles is becoming widespread among consumers, demonstrating that companies need to be able to disclosure information. Given that avoiding transparency is becoming more and more difficult for the brands, those who keep doing business as usual will eventually lose their clients. This actually appears to be one of the strongest motivations for fashion brands to improve their supply chain disclosure performance.

Fashion Revolution has successfully raised public awareness about the importance of transparency. This resulted in millions of people calling out fashion brands to answer who actually made the clothes. In the end, what emerges is that the final influence on the fashion companies is actually remarkable. This is confirmed by a significant increase in terms of the number of companies disclosing information. That is, Fashion Transparency Index revealed that 37\% of 150 major global fashion brands disclosed information about their manufacturers in 2018, a rise from $12.5 \%$ in 2016 . An average $5 \%$ increase was witnessed between 2017 and 2018 relating to supply chain transparency amongst 98 major global fashion companies.

\subsection{Effects on Collaboration}

During the last decade, Group 1 has shown progress by adopting a radical shift in terms of supplier management strategies, moving from compliance to collaboration. Group 1 has opted to directly work with their business partners rather than pursuing basic efforts such as audits and checklists. In addition to acknowledging the market signals, top management commitment was also ensured to improve supply chain sustainability and transparency. In this direction, a specific team (Responsible Sourcing team) was established to improve sustainability across the portfolio brands. For Group 1, NGOs influence has become central to detect issues and topics that the group was not aware of otherwise. Brand T, and consecutively Group 1, has improved their Fashion Transparency Index performance over the years. By acknowledging what Fashion Revolution demands and by providing evidence-based supply chain information, Brand $\mathrm{T}$ has improved their transparency score. To illustrate, the level of traceability was roughly $40 \%$ in 2018, it was increased to $68 \%$ in 2019 and it is scored more than $80 \%$ in 2020 . NGOs and companies evidently cooperate to address issues with the latter sometimes representing the proactive part, as in the case of Group 1. This cooperation allows to further engage other supply chain partners in practices, resulting in enhanced supply chain visibility.

Collaborative relations with the suppliers can be accelerated by the brands, considering their purchasing power. Thus, willingness and commitment are fundamental to engage supply chain actors and enhance transparency. Supplier involvement, driven by their clients, help ensure sustainability improvement and is deemed fundamental for spreading sustainability upstream. To summarize, as illustrated by Figure 1, it can be roughly interpreted that NGOs influence the consumers to demand transparency and pressure the companies. Companies, relatedly, feel the need to provide information for which they look up at their supply chains partners to collect, analyze and disclose information.

However, this study could not differentiate the specific impact of NGOs on supply chain collaboration for transparency enhancement. Nevertheless, it is sufficient to summarize that NGOs' pressure is an essential driver that motivates companies to begin and to sustain a transparency enhancement process while it requires an effective internal commitment to avoid greenwashing [51]. 


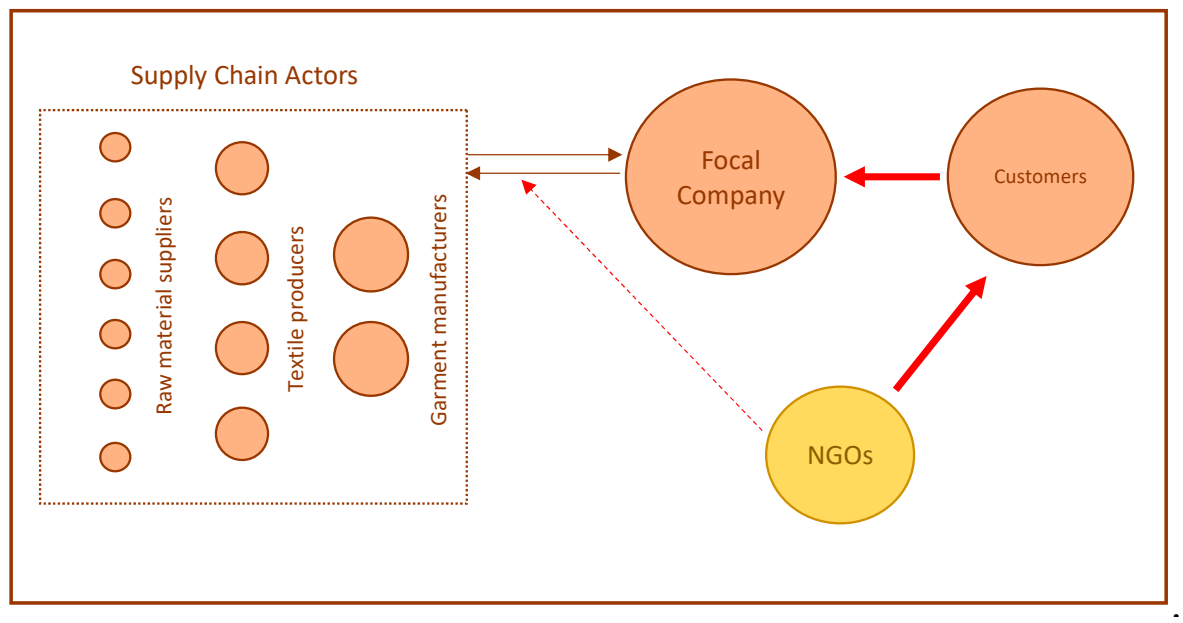

Figure 1. The Influence of NGOs on Supply Chain Collaboration.

\section{Conclusions}

From a multidisciplinary perspective, this paper responds to some theoretical questions and addresses supply chain transparency by exploring supply chain relations under the influence of NGOs. Specifically, it shows that supplier engagement and joint actions are needed to improve supply chain sustainability at large; however, supply chain visibility and strong relations are needed to overcome problems relating to supply chain complexity on the way toward transparency. Supply chain information can be disclosed once brands are able to identify their supply partners and address what really happens across their chains. Top management commitment and leadership are required to form strong supply chain relations, which, consequently, enable trust-based information sharing practices. In this vein, multi-stakeholder engagements are fundamental and, therefore, NGOs play a pivotal role to bring a wide range of stakeholders into the conversation to demand enhanced transparency. The results provide numerous implications that can help industrial practice and research. First of all, managers must disclose a higher amount of supply chain information because the pressure coming from external stakeholders is only growing. Fashion companies could use the findings to understand which information a company should disclose to enhance transparency. As such, Group 1 can be considered a good example to be followed. The company alone is not able to provide all this information and it is therefore necessary to involve and engage supply chain partners. Further, collaborative relations are needed to create joint resolution techniques. It is equally important to notice that a company must be aware of the importance of stakeholder management. It is vital for the managers to understand that NGOs are not a source of risk damaging the bottom line of their firms, but rather are actors helping the companies to understand where their transparency performances could be improved. Companies should actually change their mentality toward open and transparent information sharing, as the end consumers seek nothing but the truth.

\subsection{Managerial Implications}

In supply chains characterized by trust deficits, power imbalance and fragmented dispersion, there are substantial bottlenecks preventing supply chain integration. However, building long-term and constructive collaborations between supply chain actors is one of the main antecedents to supply chain sustainability. NGOs are engaging with a number of stakeholders to ask questions, demand transparency and bring lower tier suppliers' complex problems to the spotlight. An inclusive conversation in which a constructive language is used can substantially change supply chain dynamics, can reduce information asymmetry, and can, subsequently, improve the disclosure quality. Figure 2 is developed to show the extent to which the level of trust and collaboration can influence supply chain sustainability and supply chain transparency. For example, companies that aim at legitimacy are committed to basic monitoring and low level of supply chain information disclosure. To this end, 
supplier relations are not seen being established based on trust and level of strong collaborations is low. Conversely, relations based on trust might lead to joint resolution techniques by which technical and financial support can be delivered to the suppliers. Beyond that, it becomes evident that the level of collaboration and the level of trust directly affect supply chain visibility that influences supply chain sustainability and transparency.

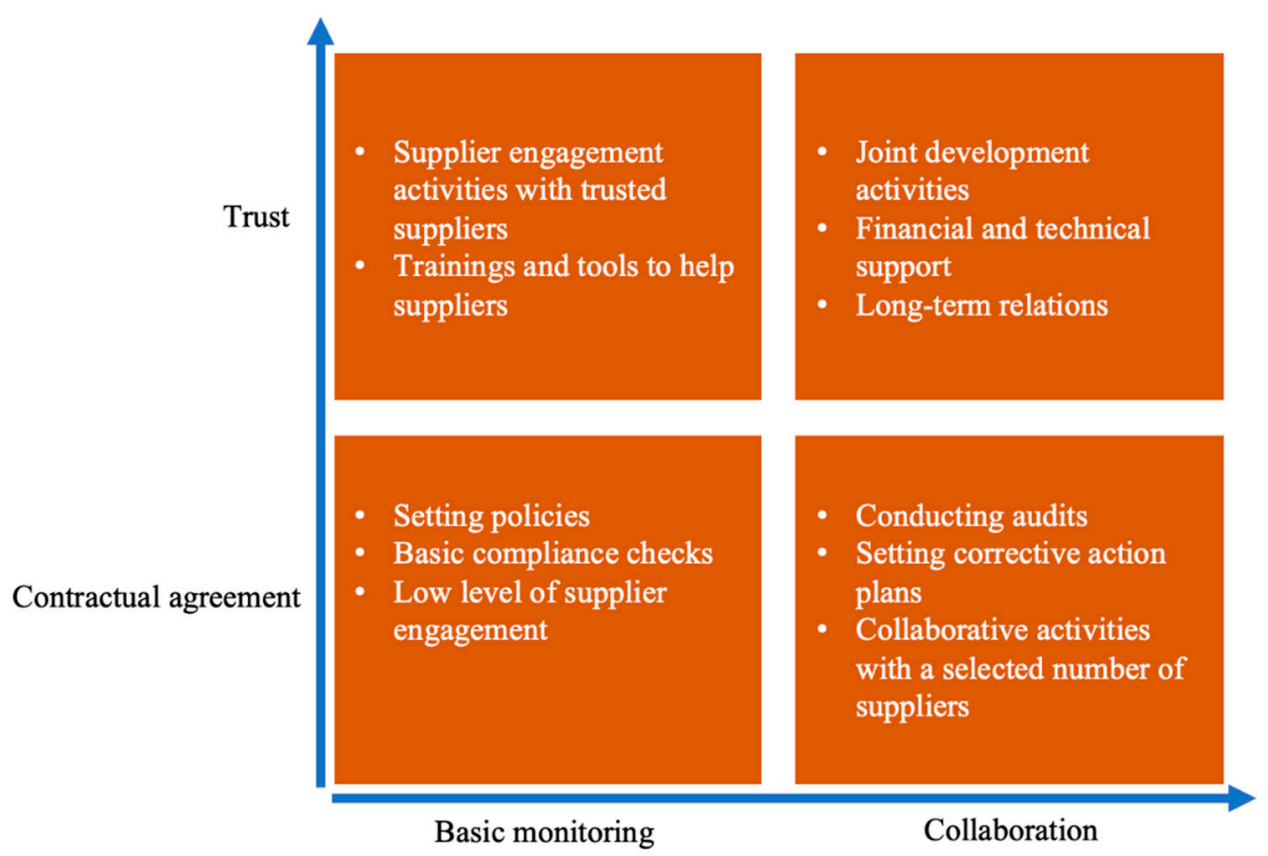

Figure 2. Supply Chain Collaboration Matrix.

Managers from fashion companies and/or other industries that have similar supply chain settings are encouraged to form stronger relations to with their supply chain partners. Several suggestions can be drawn to help them start taking actions.

1. Supply chain visibility: Get to know who operates within your operational landscape and beyond

2. Supplier integration: Build relations and understand how supply chain members can be helped

3. Capacity building: Develop tools and mechanisms to share with your supply chain members in order to help improve supply chain performance.

4. Measure and improve: Use scientific tools and performance indicators to measure your supply chain performance throughout.

5. Disclose and be transparent: Disclose evidence-based information about your supply chain. Honesty and the truth are what today's consumers are seeking.

6. Share, engage and join forces with multi-stakeholders to bring the change holistically.

\subsection{Limitations}

While providing some interesting and novel insights, the study has some limitations. First of all, adopting a single case study has some limitations. Future research can, therefore, take certain approaches to increase robustness. Firstly, investigating multiple fashion companies that are reported by the annual Fashion Transparency Index could help explore supply chain transparency at a larger scale. For instance, investigating and comparing how different brands approach policy commitments, governance, traceability and critical issues across their supply chains could provide substantial insights to better inform supply chain literature. In fact, future studies could gather similarities and differences among collaboration practices adopted by fashion companies with their suppliers. 
Furthermore, it is suggested that future research can compare multiple fashion companies by adopting a longitudinal perspective. Additionally, fashion context can be compared for another industry with fragmented and long supply chains under NGO scrutiny, such as food or electronics. In particular, this could result in insightful outcomes by elaborating the NGO's role in increasing the knowledge about supply chain transparency across multiple industrial settings. Furthermore, difficulties and barriers faced by supply chain partners in forming collaborative actions could be another interesting angle for future research. To this end, exploratory interviews are needed with lower tier supply chain actors. Future research is encouraged to uncover lower tier supply chain stages, for example raw material processors in fashion supply chains, to capture the darker side of the business reality in terms of contractual pressures, power imbalance and information asymmetry.

Alternatively, this study embedded in supply chain and sustainability literatures can benefit from other disciplines such as sociology (by investigating the perception of transparency between supply chain actors) and fashion design (by exploring how design can influence supply chain transparency). Further, the third research question has obtained only partial results in terms of the NGOs' actual impact on the collaborative actions between the brand owners and their suppliers. Therefore, future researches could further elaborate this to get a more holistic view. Lastly, there is a growing literature on the application of technology-driven applications and their impact on traceability [60]. Despite its growing importance though, the full potential and critical aspects of the blockchain technology is yet to be explored in the operations management literature [68]. Future research can therefore take a specific perspective by investigating if, how and to what extent innovation, such as blockchain, can enhance traceability and transparency in supply networks.

Author Contributions: Conceptualization, A.B., H.K.; methodology, H.K. and T.B.; data analysis, T.B.; data curation, H.K., T.B.; writing-original draft preparation, H.K.; writing—review and editing, A.B., H.K., T.B.; supervision, A.B.; project administration, H.K. All authors have read and agreed to the published version of the manuscript.

Funding: This research received no external funding.

Conflicts of Interest: The authors declare no conflict of interest.

\section{Appendix A}

\section{The Interview Protocol}

\section{Introductory Questions}

- Can you tell me a bit about your current position within the organization?

- Can you give me some background about the organization?

Questions (Brand)

- How do you describe the decisions and the actions undertaken by your company in terms of $\mathrm{SC}$ transparency?

Has this intention to increase transparency been influenced by NGOs? If yes, how have you been influenced? How do you shift this pressure to suppliers?

- In enhancing transparency, what are the difficulties, bottlenecks and risks encountered in the various stages of the upstream SC?

- How did you solve these difficulties and tackle risks? How do you form collaboration? Which kind of collaboration activities do you adopt?

How do you form collaboration with suppliers? Do you use any incentive and reward system to involve them?

How do you reach out to sub-suppliers? Do you have a direct relation with them, or you implement other strategies? 
- How do you describe the lessons learned in moving from a compliance-based to a collaboration-based relationship?

- How does the pressure coming from NGOs' influence you to form or adjust collaborative actions with your suppliers?

How do you create long-lasting collaborative relationships with your suppliers?

Questions (NGO)

- Why is important to enhance transparency in a fashion supply chain?

- Which information should brand owners disclose in order to be considered more transparent?

- Which actions do you undertake to make brands aware of their level of transparency?

- How do you influence their disclosure performance? Which actions should they undertake with suppliers?

- How do you incentivize brands to go beyond basic disclosure?

- How are your actions influenced by brands' characteristics?

- Can you give me an example of a collaboration activity undertaken by brands or by suppliers that aim at enhancing transparency?

- How do you think you influence fashion brands to create or adjust collaboration activities with their suppliers?

Have you observed any improvements in terms of supplier collaborations?

\section{References}

1. WCED. Our Common Future; WCED: Oslo, Norway, 1987.

2. Beske, P.; Seuring, S. Putting sustainability into supply chain management. Supply Chain Manag. 2014, 19, 322-331. [CrossRef]

3. Rajeev, A.; Pati, R.K.; Padhi, S.S.; Govindan, K. Evolution of sustainability in supply chain management: A literature review. J. Clean. Prod. 2017, 162, 299-314. [CrossRef]

4. Karaosman, H.; Perry, P.; Brun, A.; Morales-Alonso, G. Behind the runway: Extending sustainability in luxury fashion supply chains. J. Bus. Res. 2018. [CrossRef]

5. Sodhi, M.S.; Tang, C.S. Research Opportunities in Supply Chain Transparency. Prod. Oper. Manag. 2019, 28, 2946-2959. [CrossRef]

6. Svensson, G. The transparency of SCM ethics: Conceptual framework and empirical illustrations. Supply Chain Manag. 2009, 14, 259-269. [CrossRef]

7. BBC. Bangladesh Factory Collapse. 2013. Available online: https://www.bbc.com/news/world-asia-22476774 (accessed on 12 May 2013).

8. Moulds, J. Child Labour in the Fashion Supply Chain. The Guardian. 2015. Available online: http: //labs.theguardian.com/unicef-child-labour/ (accessed on 19 January 2016).

9. Dirty Laundry 2: Hung Out to Dry; Greenpeace International: Amsterdam, The Netherlands, 2011.

10. Clean Clothes Campaign, Global Brands Leave Cambodian Workers Fainting Over Fashion. 2015. Available online: http://www.cleanclothes.org/news/press-releases/2015/12/10/global-brands-leavecambodian-workers-fainting-over-fashion (accessed on 2 January 2016).

11. Doorey, D.J. The transparent supply chain: From resistance to implementation at Nike and Levi-Strauss. J. Bus. Ethics 2011, 103, 587-603. [CrossRef]

12. Karaosman, H.; Morales-Alonso, G.; Brun, A. From a systematic literature review to a classification framework: Sustainability integration in fashion operations. Sustainability 2017, 9, 30. [CrossRef]

13. Amed, I.; Balchandani, A.; Beltrami, M.; Berg, A.; Hedrich, A.; Rölkens, F. The State of Fashion 2019. BOF McKinsey 2019.

14. Boström, M.; Micheletti, M. Introducing the sustainability challenge of textiles and clothing. J. Consum. Policy 2016, 39, 367-375. [CrossRef] 
15. Perry, P.; Towers, N. Conceptual framework development: CSR implementation in fashion supply chains. Int. J. Phys. Distrib. Logist. Manag. 2013, 43, 478-500. [CrossRef]

16. Choi, T.M.; Chiu, H.C.; To, K.M.C. A fast fashion safety-first inventory model. Text. Res. J. 2011, 81, 819-826. [CrossRef]

17. Newbold, A. Why We Need to Talk about Transparency in Fashion. Vogue 2018. Available online: https://www.vogue.co.uk/article/sustainability-transparency-traceability-fashion (accessed on 27 May 2020).

18. Sen, A. The US fashion industry: A supply chain review. Int. J. Prod. Econ. 2008, 114, 571-593. [CrossRef]

19. Crowley, H.; Driscoll-Goulay, C.; Niemtzow, E.; Norton, T.; Prattico, E.; Woods, B. Climate Change: Implications and strategies for the luxury fashion sector. BSR Work. Pap. Collab. Kering 2015, 57.

20. Black, S. The Sustainable Fashion Handbook; Thames \& Hudson: London, UK, 2012.

21. Fashion Revolution. Fanzine \#001 Money Fashion Power; Fashion Revolution: London, UK, 2017.

22. A New Textiles Economy: Redesigning Fashion's Future; Ellen MacArthur Foundation: Cowes, UK, 2017.

23. Benstead, A.V.; Hendry, L.C.; Stevenson, M. Horizontal collaboration in response to modern slavery legislation: An action research project. Int. J. Oper. Prod. Manag. 2018, 38, 2286-2312. [CrossRef]

24. Brun, A.; Castelli, C.; Karaosman, H. A focused supply chain strategy for luxury fashion management. J. Fash. Mark. Manag. 2017, 21, 2017. [CrossRef]

25. Marshall, D.; McCarthy, L.; Heavey, C.; McGrath, P. Environmental and social supply chain management sustainability practices: Construct development and measurement. Prod. Plan. Control 2015, 26, 673-690. [CrossRef]

26. Johnsen, T.E.; Miemczyk, J.; Howard, M. A systematic literature review of sustainable purchasing and supply research: Theoretical perspectives and opportunities for IMP-based research. Ind. Mark. Manag. 2016, 61, 1-14. [CrossRef]

27. Touboulic, A.; Walker, H. Love me, love me not: A nuanced view on collaboration in sustainable supply chains. J. Purch. Supply Manag. 2015, 21, 178-191. [CrossRef]

28. Seuring, S.; Muller, M. From a literature review to a conceptual framework for sustainable supply chain management. J. Clean. Prod. 2008, 16, 1699-1710. [CrossRef]

29. Duan, Y.; Aloysius, J.A. Supply chain transparency and willingness-to-pay for refurbishedpProducts. Int. J. Logist. Manag. 2019, 30, 797-820.

30. Marshall, D.; McCarthy, L.; McGrath, P.; Harrigan, F. What's your strategy for supply chain disclosure? MIT SLOAN Manag. Rev. 2016, 57, 37-45.

31. Mejías, A.M.; Bellas, R.; Pardo, J.E.; Paz, E. Traceability management systems and capacity building as new approaches for improving sustainability in the fashion multi-tier supply chain. Int. J. Prod. Econ. 2019, 217, 143-158. [CrossRef]

32. Egels-Zandén, N.; Hulthén, K.; Wulff, G. Trade-offs in supply chain transparency: The case of Nudie Jeans Co. J. Clean. Prod. 2015, 107, 95-104. [CrossRef]

33. Köksal, D.; Strähle, J.; Müller, M.; Freise, M. Social sustainable supply chain management in the textile and apparel industry-A literature review. Sustainability 2017, 9, 100. [CrossRef]

34. Moosmayer, D.C.; Davis, S.M. Staking cosmopolitan claims: How firms and NGOs talk about supply chain responsibility. J. Bus. Ethics 2016, 135, 403-417. [CrossRef]

35. Meixell, M.; Luoma, P. Stakeholder pressure in sustainable supply chain management: A systematic review. Int. J. Phys. Distrib. Logist. Manag. 2015, 45, 69-89. [CrossRef]

36. Brockhaus, S.; Fawcett, S.; Kersten, W.; Knemeyer, M. A framework for benchmarking product sustainability efforts: Using systems dynamics to achieve supply chain alignment. Benchmarking 2016, 23, 127-164. [CrossRef]

37. Chen, L.; Zhao, X.; Tang, O.; Price, L.; Zhang, S.; Zhu, W. Supply chain collaboration for sustainability: A literature review and future research agenda. Int. J. Prod. Econ. 2017, 194, 73-87. [CrossRef]

38. Dyer, J.; Singh, H. The relational view: Cooperative strategy and sources of interorganizational competitive advantage. Acad. Manag. Rev. 1998, 23, 660-679. [CrossRef]

39. Carter, C.; Easton, P. Sustainable supply chain management: Evolution and future directions. Int. J. Phys. Distrib. Logist. Manag. 2011, 41, 46-62. [CrossRef] 
40. Vachon, S.; Klassen, R.D. Environmental management and manufacturing performance: The role of collaboration in the supply chain. Int. J. Prod. Econ. 2008, 111, 299-315. [CrossRef]

41. Hartmann, J.; Moeller, S. Chain liability in multitier supply chains? Responsibility attributions for unsustainable supplier behavior. J. Oper. Manag. 2014, 32, 281-294. [CrossRef]

42. Sancha, C.; Gimenez, C.; Sierra, V. Achieving a socially responsible supply chain through assessment and collaboration. J. Clean. Prod. 2016, 112, 1934-1947. [CrossRef]

43. Gimenez, C.; Tachizawa, E.M. Extending sustainability to suppliers: A systematic literature review. Supply Chain Manag. 2012, 17, 531-543. [CrossRef]

44. Zhang, M.; Pawar, K.S.; Bhardwaj, S. Improving supply chain social responsibility through supplier development. Prod. Plan. Control 2017, 28, 500-511. [CrossRef]

45. Quarshie, A.M.; Salmi, A.; Leuschner, R. Sustainability and corporate social responsibility in supply chains: The state of research in supply chain management and business ethics journals. J. Purch. Supply Manag. 2016, 22, 82-97. [CrossRef]

46. Danese, P.; Lion, A.; Vinelli, A. Drivers and enablers of supplier sustainability practices: A survey-based analysis. Int. J. Prod. Res. 2019, 57, 2034-2056. [CrossRef]

47. Lion, A.; Macchion, L.; Danese, P.; Vinelli, A. Sustainability approaches within the fashion industry: The supplier perspective. Supply Chain Forum 2016, 17, 95-108. [CrossRef]

48. Ho, D.; Kumar, A.; Shiwakoti, N. A literature review of supply chain Collaboration mechanisms and their impact on performance. EMJ 2019, 31, 47-68. [CrossRef]

49. Liu, L.; Zhang, M.; Ye, W. The adoption of sustainable practices: A supplier's perspective. J. Environ. Manag. 2018, 232, 692-701. [CrossRef]

50. Sancha, C.; Longoni, A.; Giménez, C. Sustainable supplier development practices: Drivers and enablers in a global context. J. Purch. Supply Manag. 2015, 21, 95-102. [CrossRef]

51. Gualandris, J.; Kalchschmidt, M. Customer pressure and innovativeness: Their role in sustainable supply chain management. J. Purch. Supply Manag. 2014, 20, 92-103. [CrossRef]

52. Marshall, D.; McCarthy, L.; McGrath, P.; Claudy, M. Going above and beyond: How sustainability culture and entrepreneurial orientation drive social sustainability supply chain practice adoption. Supply Chain Manag. 2015, 20, 434-454. [CrossRef]

53. Gardner, T.A.; Benzie, M.; Börner, J.; Dawkins, E.; Fick, S.; Garrett, R.; Godar, J.; Grimard, A.; Lake, S.; Larsen, R.K.; et al. Transparency and sustainability in global commodity supply chains. World Dev. 2019, 121, 163-177. [CrossRef]

54. Carter, C.R.; Rogers, D.S. A framework of sustianable supply chain management: Moving toward new theory. J. Phys. Distrib. Logist. Manag. 2008, 38, 360-387. [CrossRef]

55. Egels-Zandén, N.; Sörum, N. Supply chain transparency as a consumer or corporate tool: The case of Nudie Jeans Co. J. Consum. Policy 2015, 39, 377-395. [CrossRef]

56. Chen, S.; Zhang, Q.; Zhou, Y.P. Impact of Supply Chain Transparency on Sustainability under NGO Scrutiny. Prod. Oper. Manag. 2019, 28, 3002-3022. [CrossRef]

57. New, S. The transparent supply chain. Harv. Bus. Rev. 2010, 88, 11.

58. Yang, C. Maritime shipping digitalization: Blockchain-based technology applications, future improvements, and intention to use. Transp. Res. Part E 2019, 131, 108-117. [CrossRef]

59. Choi, T.; Feng, L.; Li, R. Information disclosure structure in supply chains with rental service platforms in the blockchain technology era. Int. J. Prod. Econ. 2020, 221, 107473. [CrossRef]

60. Hastig, G.M.; Sodhi, M.S. Blockchain for supply chain traceability: Business requirements and critical success factors. Prod. Oper. Manag. 2020, 29, 935-954. [CrossRef]

61. Yin, R.K. Case Study Research: Design and Methods; Sage Publications: Thousand Oaks, CA, USA, 1994.

62. Yin, R.K. Case Study Research: Design and Methods; Sage: Thousand Oaks, CA, USA, 2009; Volume 5.

63. Voss, C.; Tsikriktsis, N.; Frohlich, M. Case research in operations management. Int. J. Oper. Prod. Manag. 2002, 22, 195-219. [CrossRef]

64. Yang, Y.; Han, H.; Lee, P. An exploratory study of the mechanism of sustainable value creation in the luxury fashion industry. Sustainability 2017, 9, 483. [CrossRef]

65. Katz, J.P.; Higgins, E.; Dickson, M.; Eckman, M. The impact of external monitoring and public reporting on business performance in a global manufacturing industry. Bus. Soc. 2009, 48, 489-510. [CrossRef] 
66. Brun, A.; Karaosman, H. Customer influence on supply chain management strategies: An exploratory investigation in the yacht industry. Bus. Process Manag. J. 2019. [CrossRef]

67. Pagell, M.; Wu, Z.H. Building a more complete theory of sustainable supply chain management using case studies of 10 exemplars. J. Supply Chain Manag. 2009, 45, 37-56. [CrossRef]

68. Babich, V.; Hilary, G. Manufacturing \& Service Operations Management OM Forum—Distributed Ledgers and Operations: What Operations Management Researchers Should Know About Blockchain Technology. Manuf. Serv. Oper. Manag. 2020.

(C) 2020 by the authors. Licensee MDPI, Basel, Switzerland. This article is an open access article distributed under the terms and conditions of the Creative Commons Attribution (CC BY) license (http://creativecommons.org/licenses/by/4.0/). 